\title{
Modifiable Demographic Factors that Differentiate Bronchiolitis from Pneumonia in Nepalese Children Less Than Two Years - A Hospital Based Study Malla $\mathrm{T}^{1}$ Poudyal $\mathrm{P}^{2}$ Malla KK ${ }^{1}$
}

'Department of Pediatrics
Manipal Teaching Hospital
Phulbari, Pokhara, Nepal
${ }^{2}$ Department of Pediatrics
Dhulikhel Hospital, Kathmandu University Hospital
Dhulikhel, Kavre, Nepal

Corresponding Author

Kalpana K Malla

Department of Pediatrics

Manipal Teaching Hospital

Phulbari, Pokhara, Nepal

Email: kalpana01malla@gmail.com

\section{Citation}

Malla T, Poudyal P, Malla KK. Modifiable Demographic Factors that Differentiate Bronchiolitis from Pneumonia in Nepalese Children Less Than Two Years - A Hospital Based Study. Kathmandu Univ Med J 2014;47(3):175-80.

\section{ABSTRACT}

\section{Backgroud}

Bronchiolitis and pneumonia is an important cause of mortality and morbidity in children. Various risk factors make these children more prone for this illness. There is limited data on the risk factors from this part of the world. Moreover there is a significant clinical overlap between bronchiolitis and pneumonia thus necessitating the need for evaluating their demographic difference.

\section{Objective}

To evaluate the modifiable demographic risk factors for bronchiolitis and pneumonia in children less than 2 years.

\section{Method}

A prospective, comparative hospital based study undertaken during March 2012- March 2013 in Manipal Teaching Hospital, Pokhara. Altogether 200 cases of bronchiolitis and 200 cases of pneumonia, in the age group of 2 to 24 months, were randomly selected for comparison of risk factors as per a predesigned proforma. A ' $p$ ' value of $<0.05$ was considered statistically significant. Data was analyzed by using SPPS version 16.

\section{Result}

The significant risk factors for bronchiolitis were age $<6$ months $(p<0.001)$, prematurity $(p<0.001)$, male $(P<0.04)$, younger maternal age $(p<0.009)$, poor maternal knowledge $(p<0.013)$, air pollution and lack of ventilation $(p<0.001)$, exposure to cooking fuel - kerosene $(p<0.007)$, firewood $(p<0.001)$, tobacco smoke $(p<0.001)$, overcrowding $(0.008)$, winter season $(p<0.015)$, domestic pets $(p<0.003)$, low birth weight $(p<003)$, use of animal milk $(p<0.001)$.The significant risk factors for pneumonia were age 13 months- 24 months, maternal age $26-35$ yrs $(p<0.009)$, female ( $p<$ $0.04)$, malnutrition, lack of Vitamin A supplementation and immunization $(\mathrm{p}<0.001)$.

\section{Conclusion}

Most of the risk factors for bronchiolitis and pneumonia identified in this study were modifiable; hence could be prevented to decrease the burden of both the diseases.

\section{KEY WORD}

ALRI, bronchiolitis, pneumonia, risk factors 


\section{INTRODUCTION}

Pneumonia and bronchiolitis are the commonest acute lower respiratory infections (ALRI) and represents one of the major health problems in children especially in the developing world including Nepal. Of the 6.3 million children who died before age 5 years in 2013, 51.8\% (3.257 million) died of infectious causes and Pneumonia was responsible for the deaths of 0.817-1.057 million children, which represents $14.9 \%$ of all deaths in this age group. ${ }^{1}$ Bronchiolitis is also a significant cause of respiratory disease worldwide. According to the World Health Organization (WHO) bulletin an estimated 150 million new cases of bronchiolitis occur annually and $95 \%$ of all cases occur in developing countries. ${ }^{2}$ Inspite of the high incidence, there are very little information on the risk factors for these problems in the population of this region of Nepal. Hence, the present study was designed to identify and compare the various modifiable risk factors so that it could be corrected reducing the incidence and prevalence of both the diseases.

\section{METHODS}

A hospital based comparative prospective study, conducted for a period of 1 year (March 2012 -March 2013) in the department of pediatrics, Manipal Teaching Hospital, Pokhara. Out of 5800 respiratory cases during the study period there were 650 children belonging to age group two month to 24 months. Two hundred cases of pneumonia and 200 cases of bronchiolitis who fulfilled the criteria for the study were selected and remaining 250 cases were excluded [ 230 cases had doubtful clinical, laboratory or radiological findings and 20 cases fulfilled the criteria for pneumonia but were excluded in order to compare equal number of cases in both groups]. These children were randomly selected from the outpatient and inpatient department of pediatric. The cases were examined and necessary information was collected in predesigned proforma, where special emphasis was on the age, gender, birth characteristics, socioeconomic factors, housing conditions, overcrowding, passive smoking, breast feeding, maternal age, education and knowledge on ALRI. All were subjected to total white blood cells and differential count (WBC), C - reactive protein (CRP) and radiological evaluation.

Group 1 Bronchiolitis ( $n=200$ ): diagnosis was based upon coryzal symptoms followed by dry wheezy cough, signs of respiratory distress and fine inspiratory crackles/high pitched expiratory wheeze on auscultation. ${ }^{3}$ They had either normal WBC count [6000-17,500/mm3] or negative CRP and most had normal to hyperinflated lung field on Chest X-ray. ${ }^{4,5}$

Group 2 Pneumonia ( $n=200)$ : selected as per the WHO definition - cough and/or difficulty in breathing with tachypnea, chest indrawing, absence of wheeze. ${ }^{6}$ They were either more ill looking, had high grade fever and predominantly crackles on auscultation or had high WBC count $[>17,500 / \mathrm{mm} 3]$ with neutrophil predominance $[>62 \%]^{4}$ or had positive CRP $[6 \mathrm{mg} / \mathrm{L}]^{7}$ or evidence of broncho/lobar pneumonia on chest X-ray. ${ }^{5}$

\section{Ethical committee approval}

Preceding the study, ethical approval from the institutional research ethical committee and written consent from parents was also obtained.

\section{Inclusion criteria:}

Age two months to twenty four months with pneumonia or bronchiolitis and both first and recurrent episodes were included.

\section{Exclusion criteria:}

Age below two and above 24 months, hospital acquired and aspiration pneumonia; other causes of respiratory distress like congestive heart failure and metabolic acidosis, congenital heart disease, chronic lung disease any congenital anomaly of airway and any genetic problems.

\section{Some definitions of risk factors used in the study -}

1) Gestation Age: Term: 37-42 completed gestation age. Preterm: $<37$ gestation age.

2) Socioeconomic status (SES): Assessed using Modified Kuppuswamy's Socioeconomic Status Scale in context to Nepal. ${ }^{8}$ This modified scale retains the educational and occupational criteria used for India. The family income is converted to Nepalese Rupees (NPR) in order to modify the economic criteria. To obtain the appropriate income groups in Nepal, all income groups in the modified scale are multiplied with the conversion factor.

Table I. Socioeconomic Status Scale of Kupuswamy (Urban, 1976)

\begin{tabular}{|ll|}
\hline Score Card & Score \\
\hline Education & \\
\hline Professional or Honors & 7 \\
\hline Graduate or Post-Graduate & 6 \\
\hline Intermediate or Post-High-School Diploma & 5 \\
\hline High School Certificate & 4 \\
\hline Middle School Certificate & 3 \\
\hline Primary School or Literate & 2 \\
\hline Illiterate & 1 \\
\hline Occupation Score & \\
\hline Profession & 10 \\
\hline Semi-Profession & 6 \\
\hline Clerical, Shop-owner, Farmer & 5 \\
\hline Skilled worker & 4 \\
\hline Semi-skilled worker & 3 \\
\hline Unskilled worker & 2 \\
\hline Unemployed & 1 \\
\hline
\end{tabular}




\begin{tabular}{|ll|}
\hline Score Card & Score \\
\hline Family Income Per Month (in Rs)* Score & \\
\hline$>2000$ & 12 \\
\hline $1000-1999$ & 10 \\
\hline $750-999$ & 6 \\
\hline $500-749$ & 4 \\
\hline $300-499$ & 3 \\
\hline $101-299$ & 2 \\
\hline$<100$ & 1 \\
\hline Total Score Socioeconomic Class & \\
\hline $26-29$ & Upper (I) \\
\hline $16-25$ & Middle Upper \\
\hline $11-15$ & Middle (II) \\
\hline $5-10$ & Lower Middle (III) \\
\hline$<5$ & Lower Upper Lower \\
\hline
\end{tabular}

Table II. Modified Family Income Groups in Nepalese Rupees of the Kuppuswamy's Socioeconomic Status Scale (Modified for 2009)

\begin{tabular}{|lll|}
$\begin{array}{l}\text { Family income per month } \\
\text { Original }\end{array}$ & Modified $^{\sharp}$ & Score \\
\hline$\geq 2000$ & $\geq 45751$ & 12 \\
\hline $1000-1999$ & $22851-45750$ & 10 \\
\hline $750-999$ & $17151-22850$ & 6 \\
\hline $500-749$ & $11451-17150$ & 4 \\
\hline $300-499$ & $6851-11450$ & 3 \\
\hline $101-299$ & $2301-6850$ & 2 \\
\hline$\leq 100$ & $\leq 2300$ & 1 \\
\hline
\end{tabular}

** In this study SES was categorized as: High = Upper (I), Middle = Upper middle (II) and lower middle (III), Lower = (Upper lower (IV) and Lower (V)

3. Knowledge on ALRI: Mothers who could at least say there is cough rapid breathing, difficulty in breathing and chest indrawing in ALRI was considered to have good knowledge.

4. Atmospheric pollution: Air pollution, house ventilation and indoor pollution was considered.

5. Exposure to smoke: Exposure to cooking fuel-kerosene, wood, gas and tobacco Smoke was considered.

5. Overcrowding: Overcrowding was defined as when there were more than two people for each room in the house. ${ }^{9}$

6. Nepal has four climatic seasons:

spring: March-May

summer: June- August

autumn: September- November

winter: December- February

7. Exposure to domestic animals \& pets: This included animals, birds in house but excluded animals like cows, buffalos in sheds which is far from the house.
8. Malnutrition: Nutritional status was assessed by detail anthropometry. Height: Measured in nearest centimeter by infantometer. Weight: Measured in nearest 100 grams with the help of standardized weighing machine (Krups Empress Manual Weighing Scale). Grading of nutritional status was done by using classification by Indian Academy of Pediatrics. ${ }^{10}$

\section{Breast -feeding (BF):}

Appropriate- BF exclusively till 6 months then continued feeding till age 2 years

Not appropriate- Exclusive BF not done till 6 months or stopped BF before 2 years.

10. Complementary feeding: a) Appropriate: started at the age of 6 months. b) Inappropriate: stared before or after 6 months.

\section{Immunization as per Nepal national immunization schedule:}

a) Fully immunized - Received all vaccines as per his/her age at time of interview.

b) Not fully immunized -Not received all vaccines as per his/her age at time of interview.

c) Not immunized - Not received any vaccines at time of interview.

Statistical analysis: Data was analyzed using SPSS version 16. Chi -square test was used to examine the association between different variables and a ' $p$ ' value of $<0.05$ was considered as statistically significant.

\section{RESULTS}

It was noted that peak age for bronchiolitis was 2-6 month with mean age $9.03 \pm 4.74$ while peak age for pneumonia was 13-24 months with mean age 12.21 \pm 4.96 [Fig 1]. The socio-demographic risk factors are shown in table 1 ,

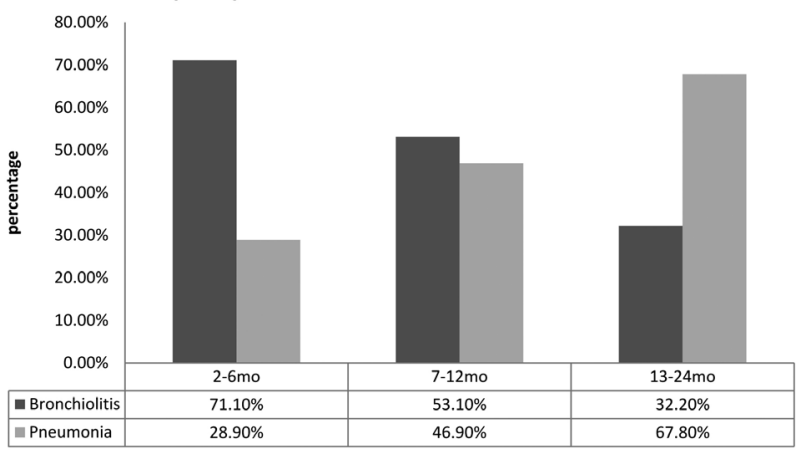

Figure 1. Age distribution of study population

Mean age bronchiolitis $=9.03 \pm 4.74$

Mean age for pneumonia $=12.21 \pm 4.96$

Equation model consisted of the following variables for table 1: gestation age $(\mathrm{OR}=2.019,95 \% \mathrm{Cl}: 1.323-3.082$, $\mathrm{P}<0.001)$, sex $(\mathrm{OR}=0.689,95 \% \mathrm{Cl}: 0.462-1.028, \mathrm{P}<0.042)$, maternal knowledge (OR=1.599, 95\% Cl: 1.074-2.381, $\mathrm{P}<0.013)$ Most of the environmental risk factors were 
Table 1. Distribution of Socio - Demographic risk factors

\begin{tabular}{|c|c|c|c|c|c|}
\hline Risk Factor & & $\begin{array}{l}\text { Bronchi- } \\
\text { olitis }\end{array}$ & Pneumonia & $\begin{array}{l}\text { Chi- } \\
\text { square }\end{array}$ & $\begin{array}{l}P \\
\text { value }\end{array}$ \\
\hline \multirow{2}{*}{$\begin{array}{l}\text { Gestational } \\
\text { age: }\end{array}$} & Term & $117(58.5 \%)$ & $148(74 \%)$ & \multirow{2}{*}{10.74} & \multirow{2}{*}{0.001} \\
\hline & Preterm & $83(41.5 \%)$ & $52(26 \%)$ & & \\
\hline \multirow{2}{*}{ Sex: } & Male & $126(63.0 \%)$ & $108(54 \%)$ & \multirow{2}{*}{3.33} & \multirow{2}{*}{0.042} \\
\hline & Female & $74(37.0 \%)$ & $92(46 \%)$ & & \\
\hline \multirow{4}{*}{$\begin{array}{l}\text { Maternal } \\
\text { age: }\end{array}$} & 16-19yrs & $7(3.5 \%)$ & $5(2.5 \%)$ & \multirow{4}{*}{11.46} & \multirow{4}{*}{0.009} \\
\hline & $20-25 y r s$ & $149(74.5 \%)$ & $121(60.5 \%)$ & & \\
\hline & $26-35 y r s$ & 37 (18.5\%) & $66(33 \%)$ & & \\
\hline & $>35 y r s$ & $7(3.5 \%)$ & $8(4 \%)$ & & \\
\hline \multirow{3}{*}{$\begin{array}{l}\text { Socioeco- } \\
\text { nomic } \\
\text { status: }\end{array}$} & High & $47(23.5 \%)$ & $41(20.5 \%)$ & \multirow{3}{*}{0.560} & \multirow{3}{*}{0.756} \\
\hline & Middle & $116(58 \%)$ & $122(61 \%)$ & & \\
\hline & Low & $37(18.5 \%)$ & $37(18.5 \%)$ & & \\
\hline \multirow{6}{*}{$\begin{array}{l}\text { Maternal } \\
\text { literacy: }\end{array}$} & Illiterate & $27(13.5 \%)$ & $19(9.5 \%)$ & \multirow{6}{*}{12.64} & \multirow{6}{*}{0.027} \\
\hline & Primary & $61(30.5 \%)$ & 39(19.5\%) & & \\
\hline & Middle & $25(12.5 \%)$ & $42(21 \%)$ & & \\
\hline & High & $43(21.5 \%)$ & $54(27 \%)$ & & \\
\hline & $\begin{array}{l}\text { Interme- } \\
\text { diate }\end{array}$ & $36(18 \%)$ & $34(17 \%)$ & & \\
\hline & Above & $8(4 \%)$ & $12(6 \%)$ & & \\
\hline \multirow{2}{*}{$\begin{array}{l}\text { Maternal } \\
\text { knowl- } \\
\text { edge: }\end{array}$} & Good & $101(50.5 \%)$ & $124(62 \%)$ & \multirow[b]{2}{*}{5.37} & \multirow[b]{2}{*}{0.013} \\
\hline & Poor & $99(49.5 \%)$ & $76(38 \%)$ & & \\
\hline
\end{tabular}

Table 3. Distribution of Nutritional and immunization risk factors

\begin{tabular}{|c|c|c|c|c|}
\hline Risk Factor & $\begin{array}{l}\text { Bronchi- } \\
\text { olitis }\end{array}$ & Pneumonia & $\begin{array}{l}\text { Chi- } \\
\text { square }\end{array}$ & $\begin{array}{l}\mathrm{P} \\
\text { value }\end{array}$ \\
\hline \multicolumn{5}{|l|}{ A) Low Birth Weight: } \\
\hline Yes & $77(38.5 \%)$ & $50(25 \%)$ & \multirow{3}{*}{11.47} & \multirow{3}{*}{0.003} \\
\hline No & $106(53 \%)$ & $139(69.5 \%)$ & & \\
\hline Unknown & $17(8.5 \%)$ & $11(5.5 \%)$ & & \\
\hline \multicolumn{5}{|l|}{ B) Malnutrition } \\
\hline Yes & $105(52.5 \%)$ & $140(70 \%)$ & \multirow{2}{*}{1.72} & \multirow{2}{*}{0.113} \\
\hline No & $95(47.5 \%)$ & $60(30 \%)$ & & \\
\hline \multicolumn{5}{|l|}{ C) Breast-Feeding } \\
\hline Appropriate & $79(39.5 \%)$ & $92(46 \%)$ & \multirow{2}{*}{1.72} & \multirow{2}{*}{0.113} \\
\hline Not appropriate & $121(60.5 \%)$ & $108(54 \%)$ & & \\
\hline \multicolumn{5}{|l|}{ D) Weaning } \\
\hline Appropriate age & $105(52.5 \%)$ & $93(46.5 \%)$ & \multirow{2}{*}{1.44} & \multirow{2}{*}{0.136} \\
\hline Inappropriate age & $95(47.5 \%)$ & $107(53.5 \%)$ & & \\
\hline \multicolumn{5}{|l|}{ E) Animal milk: } \\
\hline Yes & $165(82.5 \%)$ & $138(69 \%)$ & \multirow{2}{*}{9.92} & \multirow{2}{*}{0.001} \\
\hline No & $35(17.5 \%)$ & $62(31 \%)$ & & \\
\hline \multicolumn{5}{|l|}{ F) Vitamin A } \\
\hline supplemented & $138(69 \%)$ & $152(76 \%)$ & \multirow{3}{*}{32.41} & \multirow{3}{*}{0.001} \\
\hline not supplemented & $5(2.5 \%)$ & $27(13.5 \%)$ & & \\
\hline Not yet (<6month) & $57(28.5 \%)$ & $21(10.5 \%)$ & & \\
\hline \multicolumn{5}{|l|}{ G) Immunization status } \\
\hline Fully Immunized & $191(95.5 \%)$ & $169(84.5 \%)$ & \multirow{3}{*}{13.511} & \multirow{3}{*}{0.001} \\
\hline Not Fully Immunized & $4(2 . \%)$ & $12(6 \%)$ & & \\
\hline Not immunized & $5(2.5 \%)$ & $19(9.5 \%)$ & & \\
\hline
\end{tabular}

Table 2. Distribution of Environmental risk factors

\begin{tabular}{|c|c|c|c|c|c|}
\hline \multicolumn{2}{|l|}{ Risk Factor } & Bronchiolitis & $\begin{array}{l}\text { Pneumo- } \\
\text { nia }\end{array}$ & $\begin{array}{l}\text { Chi- } \\
\text { square }\end{array}$ & $\begin{array}{l}P \\
\text { value }\end{array}$ \\
\hline \multicolumn{6}{|c|}{$\begin{array}{l}\text { A) Atmospheric pol- } \\
\text { lution: }\end{array}$} \\
\hline \multirow{2}{*}{$\begin{array}{l}\text {-Outdoor air } \\
\text { pollution }\end{array}$} & Yes & $157(78.5 \%)$ & $98(49 \%)$ & \multirow{2}{*}{37.65} & \multirow{2}{*}{0.001} \\
\hline & No & $43(21.5 \%)$ & $102(51 \%)$ & & \\
\hline \multirow{2}{*}{$\begin{array}{l}\text {-Indoor: Poor } \\
\text { House ventila- } \\
\text { tion }\end{array}$} & Yes & $137(68.5 \%)$ & $77(38.5 \%)$ & \multirow[b]{2}{*}{36.17} & \multirow[b]{2}{*}{0.001} \\
\hline & No & $63(31.5 \%)$ & $123(61.5 \%)$ & & \\
\hline \multirow{2}{*}{\multicolumn{6}{|c|}{$\begin{array}{l}\text { B) Exposure to smoke: } \\
\text { - Domestic biomass } \\
\text { pollution cooking fuel: }\end{array}$}} \\
\hline & & & & & \\
\hline \multirow{2}{*}{ Kerosene } & Yes & $7(3.5 \%)$ & $0(0 \%)$ & \multirow{2}{*}{7.12} & \multirow{2}{*}{0.007} \\
\hline & No & 193(96.5\%) & $200(100 \%)$ & & \\
\hline \multirow{2}{*}{ Wood } & Yes & $150(75 \%)$ & $93(46.5 \%)$ & \multirow{2}{*}{34.06} & \multirow{2}{*}{0.001} \\
\hline & No & $50(25 \%)$ & $107(53.5 \%)$ & & \\
\hline \multirow{2}{*}{ Gas } & Yes & $94(47 \%)$ & $148(74 \%)$ & \multirow{2}{*}{30.5} & \multirow{2}{*}{0.001} \\
\hline & No & $106(53 \%)$ & $52(26 \%)$ & & \\
\hline \multirow{2}{*}{ Wood + Gas } & Yes & $51(25.5 \%)$ & $41(20.5 \%)$ & \multirow{2}{*}{1.41} & \multirow{2}{*}{0.142} \\
\hline & No & $149(74.5 \%)$ & $159(79.5 \%)$ & & \\
\hline \multirow{2}{*}{$\begin{array}{l}\text { - Environmental } \\
\text { tobacco smoke }\end{array}$} & Yes & $167(83.5 \%)$ & $106(53 \%)$ & \multirow{2}{*}{42.9} & \multirow{2}{*}{0.001} \\
\hline & No & 33 (16.5\%) & $94(47 \%)$ & & \\
\hline \multirow{2}{*}{ C) Crowding: } & Yes & $140(70 \%)$ & $116(58 \%)$ & \multirow{2}{*}{6.250} & \multirow{2}{*}{0.008} \\
\hline & No & $60(30 \%)$ & $84(42 \%)$ & & \\
\hline
\end{tabular}

D) Contact with ARI:

$\begin{array}{rll}\text { ARI in Mother } & 33(16.5 \%) & 25(12.5 \%) \\ \text { ARI in Sibling } & 48(24 \%) & 59(29.5 \%) \\ \text { ARI in both } & 71(35.5 \%) & 73(36.5 \%) \\ \text { No ARI contact } & 48(24 \%) & 43(21.5 \%)\end{array}$

E) Seasonal Exposure:

$\begin{array}{rllll}\text { Summer } & 38(19 \%) & 35(17.5 \%) & & \\ \text { Autumn } & 43(21.5 \%) & 60(30 \%) & & \\ \text { Winter } & 77(38.5 \%) & 50(25 \%) & & 0.015 \\ \text { Spring } & 42(21 \%) & 55(27.5 \%) & & \end{array}$

F) Exposure to Domes-

tic animals \& pets:

$\begin{array}{lllll}\text { Yes } & 60(30 \%) & 36(18 \%) & 7.89 & 0.003 \\ \text { No } & 140(70 \%) & 164(82 \%) & & \end{array}$

statistically significant for bronchiolitis as compared to pneumonia [Table 2]. For the significant variables Odds ratio and $95 \%$ confidence intervals were : outdoor air pollution ( $\mathrm{OR}=0.263,95 \% \mathrm{Cl}: 0.170-0.407, \mathrm{P}<0.001)$, indoor poor house ventilation( $\mathrm{OR}=3.474,95 \% \mathrm{Cl}$ : $2.300-$ $5.247, \mathrm{P}<0.001)$, cooking fuel pollution [kerosene (OR= 0.491, 95\% Cl: 0.444-0.543, $\mathrm{P}<0.007$ ), wood (OR=0.290, $95 \% \mathrm{Cl}: 0.190-0.443, \mathrm{P}<0.001)$, gas $(\mathrm{OR}=3.209,95 \% \mathrm{Cl}$ : 2.107-4.888, $\mathrm{P}<0.001)$ ], tobacco smoke $(\mathrm{OR}=0.223,95 \%$ $\mathrm{Cl}: 0.140-0.355, \mathrm{P}<0.001)$, crowding (OR=0.592, 95\% Cl: $0.392-0.894, P<0.008)$, exposure to pets ( $O R=0.512,95 \%$ $\mathrm{Cl}: 0.320-0.820, \mathrm{P}<0.003)$. Nutrition and immunization risk factors were highly significant [table 3]. The Odd's ratio with $95 \%$ confidence interval for these variables were : low 
birth weight $(\mathrm{OR}=95 \% \mathrm{CI} \mathrm{P}<0.003)$, malnutrition ( $\mathrm{OR}=2.111$, 95\% Cl: $1.400-3.183, \mathrm{P}<0.001)$, animal milk (OR=0.472, $95 \% \mathrm{Cl}: 0.294-0.757, \mathrm{P}<0.001)$, vitamin A supplementation (OR=0.267, 5\% Cl 0.123-0.578, $\mathrm{P}<0.001$ ) and immunization status (OR=3.128, 95\% Cl: 0.991-9.869, $\mathrm{P}<0.001)$.

\section{DISCUSSION}

Many studies have been carried out on various risk factors like environmental, nutritional, behavioral, socio-economic and demographic for pneumonia and bronchiolitis individually, but there are hardly any comparative studies done. Hence, in this study the risk factors were compared between bronchiolitis and pneumonia. To make a better comparison, equal number of children between age 2 months to 2 years were chosen as this is the age in which bronchiolitis occurs and also the burden of pneumonia is likely to be highest. ${ }^{11}$ Even in Nepal, similar\scenario was reported where $52.0 \%$ children below two years of age had ALRI, where $68.4 \%$ had pneumonia and $31.6 \%$ had acute bronchiolitis. ${ }^{12}$ In this study, bronchiolitis was noticed more during infancy with peak at 2-6 month of age. Highest risk of bronchiolitis at 3-6 months was also observed in another study. ${ }^{13}$ The reason for higher rate of bronchiolitis during infancy is that $75 \%$ of cases of bronchiolitis is caused by Respiratory Syncitial Virus (RSV) and around $70 \%$ of all infants are infected with RSV in their first year of life. ${ }^{14}$ Infants younger than 6 months are more severely affected with bronchiolitis because of their smaller, more easily obstructed airways and their inability to clear secretions. According to other authors higher incidence of pneumonia was reported in children less than one year. ${ }^{15}$ But in our study the peak age for pneumonia was at 13-24 months. The possible explanation for this may be a good breast feeding practice in the country during infancy which is a protective factor for pneumonia. Beyond infancy, there is cessation of breast-feeding, degradation of maternal antibodies which was passively transferred during birth, and attendance at child-care centers hence increasing the incidence of pneumonia.

Bronchiolitis occurs 1.25 times more frequently in males than in females; the exact reason for this difference is unknown. ${ }^{16}$ We also found an increased risk of bronchiolitis in boys compared to girls. Comparatively in this study, girls had more pneumonia (55.4\%) than bronchiolitis (44.6\%). The explanation may be that girls in this gender bias country maybe more malnourished than boys, again a significant risk factor for pneumonia. However the relation of malnutrition with sex was not assessed in this study.

Like in other studies, preterms and LBW were significant risk factors for bronchilitis. ${ }^{17}$ They tend to have impaired lung function either due to bronchopulmonary dysplasia secondary to mechanical ventilation or to disruption of integrated development of airways and alveoli. ${ }^{18,19} \mathrm{~A}$ significant difference was noticed with younger maternal age for bronchiolitis $(p<0.009)$. This was also noted by
Martinez et al. ${ }^{20}$ Mothers in pneumonia group had better knowledge on ALRI than mothers in bronchiolitis group $(p<0.013)$. The reason for this maybe younger age of mothers in bronchiolitis group with less experience.

Both indoor and outdoor air pollution, exposure to smoke was highly significant risk factors for bronchiolitis. The main source of indoor air pollution globally is the combustion of biomass fuels (wood, dung, charcoal) as this is the main source of domestic energy. They produce small amounts of energy but large amounts of indoor pollutants. Combustion of biomass fuels emits a variety of pollutants including, nitrogen dioxide $\left(\mathrm{NO}_{2}\right)$, carbon monoxide (CO), sulphur dioxide $\left(\mathrm{SO}_{2}\right)$ and hydrocarbons. Various studies, [have reported higher incidence of ALRI where wood was used for fuel. ${ }^{21,22}$ Investigators in both industrialized and developing countries have demonstrated a 1.5 to four-fold increased incidence of pneumonia among children whose parents smoke. ${ }^{23}$ In this study bronchiolitis was significantly high than pneumonia when exposed to tobacco smoke.

Similar to other study, winter season was significant risk factor for bronchiolitis. ${ }^{24}$ We found no clear seasonal variation for pneumonia. But seasonal trends in the incidence of $\mathrm{ALRI}$ and invasive pneumococcal disease have been described, with highest incidence in the spring and lowest in the fall. ${ }^{25}$ The lack of seasonal variation for pneumonia in this study could reflect the similar growth patterns of various infectious agents throughout the year. Similar to other study, exposure to domestic animal \& pets was another significant risk factor associated with bronchiolitis. ${ }^{26}$

Other significant risk factors noted in this study were malnutrition, lack of Vit A supplementation, introduction to cow's milk and lack of immunization. Investigators have documented a 12- to over 20-fold greater incidence of pneumonia in undernourished children due to decreased immunity, ${ }^{27}$ Vitamin A deficiencies, which often accompany protein-calorie malnutrition, results in keratinization of the respiratory epithelium and depression of immune response, thus presumably decreasing both local and systemic resistance to bacterial colonization and infection. Bloem have suggested a two- to four-fold increase in the relative risk of $A R I$ with vitamin $A$ deficiency. ${ }^{28}$ Similar to this study, other authors have also observed lack of immunization and early introduction of cow's milk as risk factor for pneumonia. ${ }^{29,30}$

Since the risk factors for bronchiolitis were found to be similar to triggering factors for bronchial asthma a family history of bronchial asthma and atopy should have been considered in this study. Though bronchiolitis is mostly due to infection by RSV, the pathogenesis and pathology following the infection is similar to that of bronchial asthma. A Study states that a pre-existing atopy may be a marker for more severe bronchiolitis. ${ }^{31}$ This may be the reason why the triggering factor for bronchial asthma and risk factors for bronchiolitis is similar. 


\section{CONCLUSION}

The present study has identified and compared various modifiable risk factors for bronchiolitis and pneumonia which can be tackled by effective education of the community. These data are important to establish further studies which may give a guide for specific interventions and help to decrease the burden and trends of disease for both outpatient and inpatient visits.

\section{Limitaions of the study}

The limitations of this study are 1) Diagnosis of bronchiolitis and pneumonia was made on clinical grounds due to lack of facility for isolation of virus and in maximum cases of

\section{REFERENCES}

1. Li Liu, Shefali O, Daniel H, Jamie P, Igor R, Joy E L, et al. Global, regional, and national causes of child mortality in 2000-13, with projections to inform post-2015 priorities: an updated systematic analysis. The Lancet 2013;380:2095-2128.

2. Rudan I, Tomaskovic L, Boschi-Pinto C Harry Campbell: Global estimate of the incidence of clinical pneumonia among children under five years of age. Bull World Health Organ 2004; 82:895-903.

3. Barry W, Cockburn F, Cornall R, Price J F, Sutherland G, A Vardag. Ribavirin aerosol for acute bronchiolitis. Archives of Diseases in Childhood 1986,61:593-7.

4. Robert M. Kliegman, Richard E Behrman, Hal B Jenson, Bonita F Stanton. Nelson Text Book of Pediatrrics: Reference ranges for laboratory tests and procedures In $18^{\text {th }}$ ed. WB Saunders Company, Harcourt Asia Pte Ltd: 2000;2179-2228.

5. Kuhn JP, Slovis TL, Silverman FN. Pulmonary infection: In Silverman FN, Kuhn JP (Eds): Caffey's Pediatric X-Ray Diagnosis ( $9^{\text {th }}$ ed). St Louis: Mosby 1993, 511-60.

6. World Health Organization: Acute respiratory infections in children. Case management in small hospitals in developing countries 1990, Geneva:WHO.

7. BenGershom E, Briggeman-Mol GJ, de Zegher F. Cerebrospinal fluid C-reactive protein in meningitis: Diagnostic value and pathophysiology. Eur J Pediatr 1986;145:246C-r

8. Ghosh, A Ghosh, T Modification of Kuppuswamy's Socioeconomic Status Scale in context to Nepal. Indian Pediatrics Dec2009;46(12):1104

9. World Bank's World Development Indicators: Overcrowded Homes. 20 Populations living in the most overcrowded conditions 2005, Produced by the SASI group (Sheffield) and Mark Newman (Michigan): Map 192.

10. OP Ghai, P Gupta, VK Paul. Ghai Essential Pediatrics: Nutrition and macronutrient disorders In $6^{\text {th }}$ ed. 2008; 93-118.

11. Hortal M, Benitez A, Contera M, Etorena P, Montano A, Meny M. A community-based study of acute respiratory tract infections in children in Uruguay. Rev Infect Dis 1990; 12Suppl 8S: 966-73.

12. Rijal P, Sharma A, Shrestha S, S Upadhyay. Profile of acute lower respiratory tract infection in children under fourteen years of age at Nepal Medical College Teaching Hospital. Nepal Med Coll J 2011;13:58-61.

13. Victora CG: Risk factors for acute lower respiratory infections, In: Respiratory infections in children, [edited by] Yehuda Benguigui, Francisco J. Lopez Antunano, Gabriel Schmunis, Joao Yunes. Washington, D.C., Pan American Health Organization [PAHO], Division of Disease Prevention and Control, Communicable Diseases Program, Integrated Management of Childhood IIIness 1999; Series HCT/AIEPI1.1: 41-58.

14. Glezen WP, Taber LH, Frank AL, Kasel JA: Risk of primary infection and reinfection with respiratory syncytial virus. Am J Dis Child 1986; 140:543-6. pneumonia blood culture are negative. Hence there could be some overlapping of cases. 2) This is only a hospital based study so a community based study with larger population could give better results.

\section{ACKNOWLEDGEMENT}

We thank the mothers and children who participated in this study. We are also thankful to Dr. Kiran Panthe and Dr. Prabha Chettri for helping us with data collection. We also express our gratitude to Professor and head of department of pediatrics Dr. K Seshagiri Rao for granting us permission to do the study.

15. Berman S, Mclntosh K. Selective primary health care: Strategies for control of disease in the developing world. XXI. Acute respiratory infections. Reviews of Infectious Diseases 1985; 7: 674-91.

16. Weber MW, Mulholland EK, Greenwood BM. Respiratory syncytial virus infection in tropical and developing countries. Trop Med Int Health 1998; 3: 268-80.

17. Holman RC, Shay DK, Curns AT, Lingappa JR, Anderson LJ. Risk factors for Bronchiolitis associated deaths among infants in the United States. Pediatr Infect Dis J. 2003; 22:483-90.

18. Barman W. Long-term follow-up of bronchopulmonary dysplasia. J Pediatr 1986; 109:45-50.

19. Green M. Variability of maximum expiratory flow-volume curves. J Appl Physiol 1974; 37: 67-72.

20. Martinez FD, Wright AL, Holberg CJ. Maternal age as a risk factor for wheezing lower Respiratory illnesses in the first year of life. Am J Epidemiol 1992; 136:1258-68.

21. Collings DA, Sithole SD, Martin KS. Indoor wood smoke pollution causing lower respiratory disease in children. Trop Doct 1990; 20:151-5.

22. Pandey MR, Neupane RP, Gautam A, Shrestha IB. Domestic smoke pollution and acute respiratory infections in a rural community of the hill region of Nepal. Environ Int 1989; 15: 337-40.

23. Yue Chen, Wanxian Li, Shunzhang Yu. Influence of passive smoking on admission for respiratory illness in early childhood. Br Med J 1986; 293: 303-6.

24. Panozzo CA, Fowlkes AL, Anderson LJ. Variation in timing of respiratory syncytial virus outbreaks: lessons from national surveillance. Pediatr Infect Dis J 2007; 26 (Suppl 11S):41-5.

25. Brody JA. Lower respiratory illness among Alaskan Eskimo children. Arch Environ Health 1965; 11:620-3.

26. Graham NM. The epidemiology of acute respiratory infections in children and adults: a global perspective. Epidemiol Rev 1990; 12:149-78.

27. Berman S, Duenas A, Bedoya A. Acute lower respiratory tract illnesses in Cali, Colombia: a two-year ambulatory study. Pediatrics 1983; 71:210-8.

28. Bloem MW, Wedel M, Egger RJ. Mild vitamin A deficiency and risk of respiratory tract diseases and diarrhea in preschool and school children in northeastern Thailand. American Journal of Epidemiology 1990; 131: 332-9.

29. Zafar F, Franklin W. A comparison of 'cough and cold' and pneumonia: risk factors for pneumonia in children under 5 years revisited: International Journal of Infectious Diseases 2002; 6: 294-301.

30. Carvalho Junior FF. Apresentação clínica da alergia ao leite de vaca com sintomatologia respiratória. J Pneumologia 2001; 27:17-24.

31. Bush A, Thomson AH. Acute bronchiolitis. Br Med J 2007; 335: 1037-41. 